\title{
PENGEMBANGAN USAHA KECIL MENENGAH DI TANGGULANGIN SIDOARJO
}

\author{
Moch Mahrus Fathur Rosy \\ UIN Sunan Ampel Surabaya \\ makrus_rosi@yahoo.com
}

Refita Avitriani Rizalina

UIN Sunan Ampel Surabaya

refita.rizalina@gmail.com

\author{
Mega Ayu Ningtyas \\ UIN Sunan Ampel Surabaya \\ Megahayu700@mail.com
}

\begin{abstract}
The business development of leather handicraft SME entrepreneurs in Tanggulangin does not take place instantly. In the beginning, entrepreneurs attended various training in the development of skin-based SMEs. After his knowledge was sufficient then he applied it in the field. Here the high creative power of entrepreneurs is required. With such diverse creative powers, the demand for their products will increase. The level of production increases due to increased demand from consumers. This increasing demand is the beginning of economic development at Tanggulangin so that employers need a lot of employees. If many residents in Tanggulangin are absorbed into the SME leather handicraft center, the unemployment and poverty there will automatically decrease. Each family member has high productivity because a lot of it is absorbed into the leathercraft UKM center. The higher the level of productivity of the residents there, the more evenly the income per family there, and the standard of living will increase. Tanggulangin's income and income levels increase along with the advancement of UKM there. This can be an income from the city of Sidoarjo itself if the revenue from Tanggulangin continues to be constant from year to year.
\end{abstract}

Keywords: Crafts, entrepreneurs, SMEs, Tanggulangin.

Abstrak: Pengembangan bisnis para pengusaha UKM kerajinan kulit di Tanggulangin tidak berlangsung secara instan. Para pengusaha pada awal mulanya mengikuti berbagai pelatihan dalam hal pengembangan UKM berbasis kulit. Setelah ilmunya sudah cukup memadai kemudian ia menerapkannya di lapangan. Di sini dituntut daya kreativitas yang tinggi dari para pengusaha. Dengan daya kreativitasnya yang beranekaragam itulah maka permintaan dari hasil produksinya akan meningkat. Tingkat hasil produksi meningkat dikarenakan meningkatnya permintaan dari konsumen. Permintaan yang meningkat inilah awal dari pengembangan perekonomian di Tanggulangin, sehingga pengusaha membutuhkan

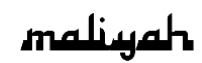

Jurnal Hukum Bisnis Islam

Volume 8, Nomor 2, Desember 2018

p-ISSN: 2088-4869/ e-ISSN: 2597-4351 
karyawan yang banyak. Apabila warga di Tanggulangin banyak yang terserap ke sentra UKM kerajinan kulit maka otomatis jumlah pengangguran dan kemiskinan di sana akan berkurang. Setiap anggota keluarga memiliki produktivitas yang tinggi karena banyak yang terserap ke sentra UKM kerajinan kulit. Semakin tinggi tingkat produktivitasnya warga di sana maka semakin merata pula pendapatan per keluarga di sana dan taraf hidupnya akan naik. Tingkat pendapatan dan pemasukan Tanggulangin meningkat seiring majunya UKM di sana. Hal itu bisa menjadi pemasukan dari kota Sidoarjo sendiri apabila pendapatan dari Tanggulangin terus konstan dari tahun ke tahun.

Kata Kunci: Kerajinan, pengusaha, UKM, Tanggulangin.

\section{Pendahuluan}

Bisnis UKM di Indonesia mulai tumbuh sekitar tahun 1970. Sekitar tahun 1975-1990 mulai bermunculan sentra industri kulit di beberapa daerah seperti Magetan, Garut, Madiun dan Tanggulangin. Pada saat jumlah pabrik juga mengalami peningkatan, dari sekitar 200 pabrik menjadi 500 pabrik. ${ }^{1}$

Kemajuan teknologi mempengaruhi proses produksi, teknologi konvensional mulai ditinggalkan dan beralih pada teknologi yang lebih modern. Teknologi pewarnaan kulit, yang dulunya dilakukan secara manual diganti dengan mesin pewarna otomatis yang mampu mencampur warna lebih merata dengan hasil yang lebih bagus. ${ }^{2}$

Salah satu daerah sentra kerajinan kulit di Indonesia adalah Propinsi Jawa Timur, tepatnya di Kecamatan Tanggulangin Kabupaten Sidoarjo. Dilihat dari data statistik Provinsi Jawa Timur, produk tas kulit memberikan nilai yang besar terhadap total produk kulit secara keseluruhan dengan total nilai produksi dari kerajinan kulit pada tahun 2000 lebih dari 20 milyar. Dari total nilai tersebut, tas kulit menyumbangkan persentase terbesar senilai lebih dari 14

\footnotetext{
${ }^{1}$ Thee Kian Wie, Industrialisasi Di Indonesia (Jakarta: PT Pustaka LP3ES, 1996)m 87.

2 Bank Indonesia, Pola Pembiayaan Usaha Kecil (PPUK) Kerajinan Tas Kulit (Direktorat Kredit, BPR dan UMKM, 2004), 1.
}

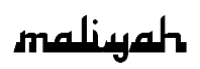

Jurnal Hukum Bisnis Islam

Volume 8, Nomor 2, Desember 2018 p-ISSN: 2088-4869/ e-ISSN: 2597-4351 
milyar $(17,42 \%)$. $^{3}$ Pada tahun 2006, banjir lumpur panas mengakibatkan banyak industri kerajinan kulit Tanggulangin gulung tikar dan hanya ada beberapa saja yang masih bertahan. Dengan kondisi seperti itu, UKM kerajinan kulit harus menyusun strategi yang tepat untuk meningkatkan profitabilitasnya. ${ }^{4}$

Tanggulangin merupakan wilayah kerajinan kulit yang memiliki harapan pengembangan yang lebih baik lagi ke depannya. Sampai kini, wilayah tersebut masih mengandalkan sebagian besar penjualan produknya $60 \%$ dari penjualan tas wanita, dan sisanya adalah keperluan lainnya mulai dari tas bepergian, dompet, ikat pinggang, dan sepatu kulit. ${ }^{5}$

"Saat ini kami memiliki 3 line mesin, di mana pada satu line terdapat 25 mesin jahit. Para karyawan yang mengerjakan bagian atas jenis sepatu sport ini, bekerja dari pukul 08.00-17.00, tanpa ada waktu lembur. Jika pesanan bertambah, perusahaan yang saat ini produksinya mencapai 1.800 pasang per hari, akan diperluas lagi".6

Penelitian ini dilakukan untuk mengetahui cara para pengusaha UKM yang berbasis kerajinan kulit di Tanggulangin dalam mengembangkan usahanya dan mengetahui keterkaitan perkembangan jumlah UKM yang berbasis kerajinan kulit di Tanggulangin dengan jumlah pengangguran dan kemiskinan di Tanggulangin.

Metode penelitian ini berbentuk penelitian lapangan. Pengumpulan data dilakukan melalui observasi, wawancara

\footnotetext{
${ }^{3}$ Direktorat Jenderal Pengembangan Ekspor Nasional, "Laporan Market Brief Produk Handbag Kulit Di Korea Selatan,” 2013, 2.

${ }^{4}$ Kurnia Sari D. S, Erma Suryani, and Radityo Prasetianto W, "Analisa Harga Dan Pemasaran Untuk Meningkatkan Profitabilitas UKM Kerajinan Kulit Dengan Sistem Dinamik (Studi Kasus: Dwi Jaya Abadi Tanggulangin Sidoarjo)," Jurnal Teknik ITS 1, no. 1 (2012), 295.

${ }^{5}$ Rizky Amalia Pratama, "Implementasi Model Manajemen Pembelian Untuk Efisiensi Biaya Pembelian Bahan Baku Menggunakan Simulasi Monte Carlo Dengan Database Adempiere Studi Kasus: UKM Kerajinan Kulit Dwi Jaya Abadi, Tanggulangin, Sidoarjo," Jurnal Teknik ITS 1, no. 1 (2012), 2.

${ }^{6}$ Mimin Sulastri, "No Title," Wawancara, Sidoarjo 22 April, 2012.
} 
dan dokumentasi. Peneliti menggunakan teknik analisis data dengan metode kualitatif deskriptif.

\section{Proses Pengembangan UKM Berbasis Kerajinan Kulit di Kecamatan Tanggulangin Kabupaten Sidoarjo}

Pada awal mulanya, sentra industri yang bergerak di bidang kerajinan kulit di daerah Tanggulangin tidak begitu saja langsung menuai hasil kesuksesan seperti saat ini. Itu semua membutuhkan waktu yang relatif lama dan membutuhkan kasabaran dan kekreatifan dari para pengusaha tersebut.

Tahap pertama yang dilakukan oleh para pengusaha tersebut yaitu dengan mengikuti pelatihan yang diadakan oleh pihak pemerintah ataupun pihak swasta. Dari ilmu yang telah dipelajarinya dalam pelatihan tersebut mereka menerapkannya ke lapangan. Seorang yang ingin memulai usaha UKM itu harus memiliki jiwa entrepreneurship yang tinggi. Itu semua dilakukan agar si pengusaha benar-benar memiliki jiwa pengusaha yang kuat. ${ }^{7}$

Tahap selanjutnya yakni bagaimana si pengusaha dapat memperoleh modal yang cukup untuk menjalankan usahanya tersebut. Kebanyakan para pengusaha kerajinan kulit di sana menggunakan modal yang berasal dari perbankan. Untuk proses pembiayaan bagi usaha kerajinan kulit di Tanggulangin, pihak bank biasanya membedakan membedakan antara pembiayaan industri kecil dan industri besar. Pembiayaan bank hanya untuk modal kerja sedangkan untuk investasi, para pengusaha dapat menggunakan modalnya sendiri. Hal trsebut disebabkan karena para pengusaha mengalami kesulitan untuk meminjam kredit investasi dari bank. Hal tersebut didasari karena masih belum adanya kepercayaan 100\% dari pihak bank terhadap para pengusaha kecil dan pihak bank masih sangat hati-hati untuk memberikan kredit investasi bagi mereka. Kredit investasi baru akan diberikan jika pengusaha

\footnotetext{
${ }^{7}$ Soesarsono Wijandi, Pengantar Kewiraswastaan (Bandung: Sinar Baru, 1998), 21.
} 
memiliki bangunan yang memadai dan pihak bank mengenal dengan baik karakter pengusaha tersebut. ${ }^{8}$

Tahap berikutnya adalah bagaimana peranan permintaan dan penawaran dari pasar mengenai produk kerajinan kulit ini. Mulai sekitar tahun 2008an sampai dengan saat ini dan seiring dengan kondisi perekonomian yang membaik, pasar produk dari kulit khususnya tas kulit mulai kembali membaik. Pengusaha kecil industri kulit dapat kembali pada produksi tas kulit asli, dan sebagian produsen tetap memproduksi tas dari kulit imitasi karena telah memiliki pangsa pasar sendiri.

Tantangan selanjutnya yang dihadapi industri tas kulit dalam negeri adalah persaingan di pasar luar negeri khususnya dari Cina. Di pasaran internasional, tas kulit dari China dipasarkan dengan harga relatif lebih murah, sedangkan produk tas kulit Indonesia yang beredar di pasar luar negeri harganya lebih mahal. Hal ini disebabkan belum adanya akses langsung ke pasar luar negeri.

Kerajinan tas kulit ini sangat memerlukan keterampilan tangan dan keuletan dari para pengrajinnya. Untuk para pengrajin di daerah Tanggulangin, mereka mempunyai slogan yaitu "tidak ada yang tidak bisa dibuat oleh pengrajin Tanggulangin". Slogan tersebut dibuat karena pengrajin Tanggulangin memiliki kemampuan yang handal dalam membuat kerajinan dari kulit. Agar tidak ketinggalan dalam hal mode tas, para pengrajin mengoleksi majalah mode dunia untuk melihat dan mengetahui trend tas kulit yang berkembang saat ini.

Di Tanggulangin telah dioperasikan Indonesian Footwear Service Center (IFSC) yang berlokasi, untuk mengembangkan produktifitas pengrajin kulit di Tanggulangin. IFSC berfungsi sebagai pusat pelatihan serta design center untuk sepatu nonsport. IFSC bertujuan untuk membuat diversifikasi produk dari Tanggulangin yang selama ini lebih dikenal sebagai produsen tas dan koper dan bertujuan untuk meningkatkan

\footnotetext{
${ }^{8}$ Bank Indonesia, Pola Pembiayaan Usaha Kecil (PPUK) Kerajinan Tas Kulit (Direktorat Kredit, BPR dan UMKM, 2004), 7.
} 
kualitas produk sepatu yang selama ini telah diproduksi walaupun terkesan sebagai produk sampingan dari daerah Tanggulangin.

IFSC ini dimaksudkan untuk menciptakan desain baru bagi industri sepatu non-sport dan untuk mendukung industri kecil dan menengah (UKM) di bidang persepatuan yang di Jatim jumlahnya kurang lebih saat ini telah mencapai 1.200 unit. Dengan adanya IFSC ini diharapkan bisa menciptakan tenaga ahli sepatu non-sport yang bisa mendongkrak industri persepatuan di Indonesia khususnya di Tanggulangin. Selain untuk desain sepatu, IFSC juga akan digunakan untuk produk kulit.

Di Tanggulangin juga terdapat sebuah koperasi yang bernama Industri Tas dan Koper (INTAKO). Tujuan didirikannya koperasi tersebut adalah untuk terjalinnya kerja sama yang lebih baik antar sesama pengrajin kulit di daerah Tanggulangin dan sebagai usaha untuk mendukung usaha pemasaran produk kulit yang lebih baik ke depannya.

Konsumen yang menginginkan model tas yang berbeda, dapat membuat desain sendiri atau memberikan contoh produk yang ia punya dan para pengrajin ini akan membuatnya sesuai selera pemesan. Pemesan juga dapat melihat contoh produk yang ada pada koleksi pengrajin kemudian meminta pengrajin untuk membuat produk modifikasinya. Para Pengusaha bahkan telah terbiasa memproduksi tas dalam jumlah ribuan dalam waktu satu minggu. Jumlah minimal dari produk pesanan konsumen tersebut tidak dibatasi oleh pengusaha.

Produk yang dihasilkan pengrajin di Tanggulangin memiliki kualitas yang baik. Produknya bisa tahan digunakan untuk waktu yang lama (lebih dari 5 tahun). Industri kerajinan kulit di Tanggulangin melibatkan pengusaha, pengrajin dan buruh. Kapasitas produksi rata-rata yang mampu dihasilkan oleh setiap pengusaha dengan 15 pengrajin dalam satu bulan adalah 200 unit tas wanita, 100 unit tas laki-laki, dan 25 unit koper besar atau tas golf. Kapasitas ini sangat tergantung dari ukuran produk dan tingkat kesulitan pembuatan produk. Jenis 
produk yang dihasilkan tas kulit, ikat pinggang, dompet, sepatu, jaket, dan gantungan kunci.

Peluang pasar yang sangat besar untuk produk tas kulit saat ini, menjadikan pengrajin harus kreatif mempromosikan produknya. Mereka sering mengadakan acara yang bertujuan untuk memperkenalkan produknya pada konsumen, melalui brosur atau internet, mengadakan pameran bersama, atau melalui bursa pasar murah produk Tanggulangin seperti Lebaran Fair dan juga pameran belanja dalam rangka memperingati hari nasional seperti hari kemerdekaan. Namun omset penjualan menjadi menurun setelah terjadinya luapan lumpur Lapindo di Porong Sidoarjo.

Terjadinya luapan lumpur Lapindo, sangat mempengaruhi penjualan para pedagang di wilayah Tanggulangin ini. Diperkirakan penurunan penjualan dari setiap ruang pamer atau toko sampai mencapai 60 persen dari besarnya omset yang kisarannya antara Rp 4 juta s/d Rp25 juta per hari. Itulah sebabnya dibentuk asosiasi dengan harapan dapat mengatasi persoalan turunnya penjualan yang dialami para pengusaha dan pedagang.

\section{Peranan UKM yang Berbasis Kerajinan Kulit dalam Pengentasan Pengangguran dan Kemiskinan di Daerah Kecamatan Tanggulangin}

UKM yang berbasis kerajinan kulit memiliki peran untuk mengentaskan pengangguran dan kemiskinan khususnya di daerah kecamatan Tanggulangin Sidoarjo. Hal tersebut dikarenakan:

1. UKM kiat utama tepis pengangguran

Terjadinya pemutusan hubungan kerja dan peningkatan pengangguran menjadi faktual keterkaitan masalah sosial dengan persoalan bisnis yang dirasakan perbankan membuat bankir perlu kerja keras mencari solusi.

Pertumbuhan penduduk Indonesia terus mengalami peningkaian dari 205.1 juta jiwa pada 2009 menjadi 222.2 juta jiwa pada 2011 atau meningkat 8.3\%. Dengan pertumbuhan ekonomi yang diprediksikan menurun, maka 
untuk mengatasi pengangguran diperlukan peningkatan jumlah pendirian usaha khususnya sektor UKM. Sesuai data Badan Pusat Statistik, usaha kecil dan menengah temyata mampu menyerap tenaga kerja hingga 85\% dari total jumlah tenaga kerja dan sebagian besar merupakan sektor agrikultur yang tersebar di seluruh Indonesia. Padahal untuk menjadi negara maju minimal jumlah wirausaha arfalah $2 \%$ dari total jumlah penduduk. Sementara itu, di Indonesia jumlah wirausaha baru mencapai $0,18 \%$ dari total populasi. Sehingga berarti masih butuh -4 juta lebih wirausahawan.

2. Pengembangan UKM bisa atasi kemiskinan

Pemberdayaan UKM merupakan salah satu cara untuk mengatasi kemiskinan. UKM terbukti memiliki daya tahan yang relatif kuat dalam menghadapi krisis ekonomi. Peran penting UKM dapat ditinjau dari beberapa aspek, yaitu jumlah unit usaha yang terbentuk, penyerapan tenaga kerja, perannya dalam peningkatan produk domestik bruto (PDB) dan sumbangannya terhadap ekspor nasional. Dalam kurun waktu 1997-2001 rata-rata unit UKM secara nasional mencapai 99,81\% dari total perusahaan yang ada. Tenaga kerja yang bekerja dalam sektor UKM ini juga mencapai $99,48 \%$ dari total pekerja nasional, selain itu UKM memberikan sumbangan hingga $55,1 \%$ kepada PDB Nasional. ${ }^{9}$ Jumlah populasi UMKM pada tahun 2008 mencapai 51,2 juta unit usaha atau 99,99\% terhadap total unit usaha di Indonesia, dengan jumlah tenaga kerjanya mencapai 90,9 juta orang atau 97,04\% terhadap seluruh tenaga kerja Indonesia. ${ }^{10}$

Tumbuhnya UKM di Tanggulangin menjadi langkah awal bagi perbaikan ekonomi nasional, dengan penciptaan lapangan kerja bagi seluruh lapisan masyarakat Jawa Timur.

\footnotetext{
${ }^{9}$ Bahrul Ulum and Aly Anwar, Saatnya Wirausahawan Muda (Makassar: Makassarpreneur Internedia, 2010).

${ }^{10}$ Reswanda, "Pengaruh Orientasi Kewirausahaan Terhadap Pembelajaran Organisasi, Keunggulan Daya Saing Berkelanjutan Dan Kinerja Usaha Pada UMKM Kerajinan Kulit Berorientasi Ekspor Di Sidoarjo," Jurnal Ekonomi Akuntansi Dan Manajemen 11, no. 2 (2012), 69.
} 
Saat ini telah disadari semua pihak bahwa pengembangan kewirausahaan di bidang UKM adalah kunci kemajuan pada suatu daerah ataupun negara. Melalui pengembangan UKM, dapat digunakan sebagai cara untuk dapat mengurangi jumlah pengangguran, menciptakan lapangan kerja, mengentaskan masyarakat dari kemiskinan dan keterpurukan ekonomis. ${ }^{11}$

Dengan banyaknya pengusaha UKM yang bergerak di bidang kerajian kulit di kecamatan Tanggulangin, maka otomatis semakin terbuka lebar juga kesempatan untuk bekerja bagi masyarakat di sana khususnya. ${ }^{12}$ Banyak masyarakat di sana yang bersyukur dengan banyaknya lapangan pekerjaan terutama di bidang UKM kerajinan kulit. Masyarakat yang sebelumnya kesulitan dalam mendapatkan pekerjaan yang dikarenakan minimnya pendidikan mereka, tetapi setelah semakin banyaknya UKM di sana terutama bergerak di bidang kerajinan kulit mereka mendapatkan angin segar yaitu terbukanya kesempatan untuk bekerja di sentrasentra UKM tersebut.

Semakin banyaknya UKM yang bergerak di bidang kerajinan kulit di Tanggulangin, maka semakin banyak pula penyerapan tenaga kerja di daerah tersebut. Dengan banyaknya penyerapan tenaga kerja ke dalam sektor UKM tersebut otomatis jumlah pengangguran di daerah tersebut dapat berkurang sedikit demi sedikit. Para pengangguran yang menginginkan bekerja di sentra UKM ini haruslah diberi pelatihan terlebih dahulu. Sehingga dari pelatihan itu

\footnotetext{
11 Ibid., 11.

12 Jumlah angkatan kerja di Indonesia sebanyak 111,4 juta orang . Dari jumlah tersebut tercatat 9,42 juta $(8,48 \%)$ orang, merupakan penganggur terbuka yang berdomisili di pedesaan (4.186.703 orang atau 44,4\%) dan di perkotaan (5.240.887 orang atau 55,6\%). Selanjutnya penduduk miskin Indonesia saat ini mencapai 34,96 juta orang (15,42\%) dengan komposisi 22.189 .122 orang $(63 \%)$ berada di desa dan 12.770 .888 orang (37\%) di kota. Dari data ini dapat kita lihat kalau jumlah pengangguran itu masih sangat banyak di Negara kita ini. Data strategis BPS bulan Agustus tahun 2008.
} 
diharapkan para pengusaha mendapatkan tenaga yang ahli di bidangnya.

Berangkat dari hasil pelatihan tersebut pengusaha UKM kerajinan kulit di sini berharap akan memperoleh hasil produksi yang banyak dan dengan kualitas yang baik. Sehingga kuantitas dan kualitas suatu barang yang diproduksinya itu tetap terjaga mutunya. Dengan terjaganya mutu barang otomatis permintaan dari pihak konsumen maupun distributor barang akan tetap konsisten.

Setelah pengangguran di daerah Tanggulangin dapat diatasi, maka setiap warga di sana dapat secara produktif untuk menghasilkan suatu output atau mempunyai penghasilan dari hasil kerjanya tersebut. Dengan semakin berkembangnya jumlah UKM yang berbasis kulit di sana, dan semakin banyaknya warga yang produktif karena terserap ke sentra UKM untuk menghasilkan uang, maka dengan sendirinya jumlah kemiskinan di daerah Tanggulangin dapat teratasi dengan baik.

\section{Peran UKM Kerajinan Kulit terhadap Pendapatan Nasional di Kecamatan Tanggulangin}

Pendapatan nasional itu bergantung pada jumlah tabungan, investasi, dan konsumsi dari masyarakat. Setelah jumlah pengangguran dan jumlah kemiskinan di daerah Tanggulangin teratasi maka produktivitas dari warganya otomatis dengan sendirinya ikut naik.

Dari hasil produktivitasnya, warga di sana akan mendapatkan pemasukan yang berupa gaji dari pihak pengusaha. Pendapatan yang mereka peroleh tersebut dapat digunakan oleh masyarakat untuk mencukupi kehidupan sehari-harinya. Uangnya tersebut dapat digunakan untuk membeli kebutuhan yang akan dikonsumsinya baik berupa kebutuhan primer maupun sekunder.

Dari sisa penghasilan yang telah dialokasikan untuk kebutuhan konsumsi, mereka dapat menggunakan sisa uangnya untuk ditabung di perbankan. Karena menurut peneliti, berawal dari perbankan inilah pendistribusian 
pendapatan nasional bisa berjalan dengan lancar. Perbankan di sini sudah tentu akan memutarkan uang yang telah ditabungkan oleh masyarakat ke dalam bank. Pihak bank suatu saat pasti akan memnijamkan dana-dana yang telah disimpan oleh penabung kepada pihak yang memerlukan, misalnya untuk seseorang yang membutuhkan dana banyak untuk usahanya.

Si peminjam tersebut sudah tentu akan menggunakan dana yang dipinjamnya untuk kebutuhan perusahaannya. Apabila dengan dana yang dipinjamnya dari bank tersebut dapat memperlancar usahanya, maka secara otomatis karyawan yang dipekerjakannya akan mendapatkan pendapatan yang konstan.

Sisa dari konsumsi warga yang bekerja di sentra UKM tersebut selain di tabungkan di perbankan, bisa juga untuk dibuat investasi mereka. Misalnya dengan membeli sebidang tanah kosong. Dari sebidang tanah kosong tersebut suatu saat bisa dijual ke orang lain, yang tentunya harganya akan melambung tinggi dari harga awal ia membelinya. Atau bisa digunakan sebagai lahan usahanya sendiri.

Pendapatan yang diperoleh masyarakat yang bertempat tinggal di Tanggulangin akan merata secara perlahan-lahan dengan semakin berkembangnya sentra UKM di sana. Dengan meratanya pendapatan dari satu keluarga ke keluarga lainnya maka maka kebutuhan akan konsumsi mereka juga akan meningkat dari sebelumnya. Yang dulunya mereka hanya mampu membeli sepeda motor tapi sekarang dengan semakin naiknya pendapatan per keluarga maka sekarang mereka mampu untuk membeli mobil.

\section{Kontribusi UKM Kerajinan Kulit terhadap Perekonomian di Kecamatan Tanggulangin}

Di sini akan membahas mengenai hubungan antara UKM dengan perekonomian di daerah Tanggulangin. Pengusaha UKM yang berbasis kerajinan kulit bisa diartikan sebagai seorang inovator dan penggerak pembangunan. UKM sangat erat kaitannya dengan pertumbuhan ekonomi. 
Pemberdayaan Usaha Kecil dan Menengah (UKM) menjadi sangat strategis, karena potensinya yang besar dalam menggerakkan kegiatan ekonomi masyarakat, dan sekaligus menjadi tumpuan sumber pendapatan sebagian besar masyarakat dalam meningkatkan kesejahteraannya. ${ }^{13}$

Ada beberapa poin penting yang perlu diperhatikan manfaat dari banyaknya UKM yang berbasis kulit di Tanggulangin saat ini di antaranya: yang pertama, pengusaha UKM tersebut mengenalkan produk baru dan kualitas baru dari suatu produk. Yang kedua, sentra UKM di sini juga mengenalkan metode baru berproduksi yang lebih komersial, baik berdasarkan pengalaman maupun hasil kajian ilmiah dari suatu penelitian. Yang ketiga, UKM juga dapat membuka pasar baru, baik dalam negeri ataupun di luar negeri. Yang keempat, UKM juga menggali sumber pasokan bahan baku baru bagi industri setengah jadi atau industri akhir, dan yang kelima yakni UKM menjalankan organisasi baru dari industri kecil menengah. Kelima hal inilah mengapa UKM dapat mendorong peningkatan pertumbuhan ekonomi suatu daerah, hal itu dikarenakan adanya peningkatan produktivitas dari suatu masyarakat yang bertempat tinggal di situ.

Tanggulangin saat ini telah menjadi sebuah pusat daerah sentra pengrajin dan souvenir yang berbasis kulit. Entah itu berupa tas, sepatu, sandal, sabuk, topi dan lain-lain. Tanggulangin sendiri sejak tahunn 2000an telah menjadi daerah sentra bisnis kerajinan yang berbasis kulit yang sangat maju dan menjadi harapan dari daerah Sidoarjo untuk mengangkat perekonomian di daerah Sidoarjo. Semenjak adanya tragedi luapan lumpur lapindo pada pertengahan tahun 2006 industri kerajinan kulit di sana agak mengalami penurunan. Mengalami kenaikan lagi itu pada sekitar tahun 2008an.

\footnotetext{
${ }^{13}$ Nunuy Nur Afiah, "Peran Kewirausahaan Dalam Memperkuat UKM Indonesia Menghadapi Krisis Finansial Global,” Universitas Padjadjaran, 2009. https://docplayer.info/36288016-Peran-kewirausahaan-dalam-memperkuat-ukmindonesia-menghadapi-krisis-finansial-global.html.
} 
Semenjak geliat industri yang bergerak di bidang kerajinan kulit mulai naik lagi, para pengusaha yang sebelumnya 'tertidur' ikut kembali lagi meramaikan persaingan di sana. Kebangkitan tersebut tidak diraih dengan begitu saja, melainkan dengan usaha yang keras. Misalnya, para pengusaha di Tanggulangin mengadakan acara yang berorientasikan ke arah pameran seperti itu di mall ataupun di pasar-pasar tradisional. ${ }^{14}$ Itu dilakukan untuk memberitahukan kepada masyarakat bahwa industri perkulitan di tanggulangin masih ada hingga saat ini. Tabel industri Kecil Kerajinan kulit Menurut Kecamatan (Tahun 2008) ${ }^{15}$.

\begin{tabular}{|c|l|c|c|c|}
\hline No & Kecamatan & Unit & $\begin{array}{c}\text { Tenaga } \\
\text { Kerja }\end{array}$ & $\begin{array}{c}\text { Hasil } \\
\text { Produksi }\end{array}$ \\
\hline $\mathbf{1}$ & Sidoarjo & 534 & 1.435 & 5.060 .127 \\
\hline $\mathbf{2}$ & Buduran & 430 & 1.712 & 3.885 .116 \\
\hline $\mathbf{3}$ & Candi & 1.043 & 3.084 & 13.048 .547 \\
\hline $\mathbf{4}$ & Porong & 575 & 2.335 & 5.765 .420 \\
\hline $\mathbf{5}$ & Krembung & 953 & 5.204 & 2.957 .052 \\
\hline $\mathbf{6}$ & Tulangan & 1.227 & 2.087 & 7.535 .673 \\
\hline $\mathbf{7}$ & Tanggulangin & 630 & 8.246 & 36.695 .975 \\
\hline $\mathbf{8}$ & Jabon & 727 & 2.314 & 2.638 .214 \\
\hline $\mathbf{9}$ & Krian & 689 & 4.410 & 4.234 .598 \\
\hline $\mathbf{1 0}$ & Balongbendo & 428 & 1.203 & 3.061 .034 \\
\hline $\mathbf{1 1}$ & Wonoayu & 578 & 1.178 & 1.450 .277 \\
\hline $\mathbf{1 2}$ & Tarik & 430 & 1.712 & 2.122 .028 \\
\hline $\mathbf{1 3}$ & Prambon & 1.043 & 3.084 & 3.296 .683 \\
\hline $\mathbf{1 4}$ & Taman & 639 & 2.659 & 6.234 .978 \\
\hline $\mathbf{1 5}$ & Waru & 1.648 & 6.792 & 19.518 .986 \\
\hline $\mathbf{1 6}$ & Gedangan & 554 & 1.954 & 15.753 .267 \\
\hline $\mathbf{1 7}$ & Sedati & 446 & 1.302 & 2.707 .582 \\
\hline $\mathbf{1 8}$ & Sukodono & 342 & 1.218 & 2.707 .582 \\
\hline
\end{tabular}

14 "Tanggulangin Shop Sumber Wirausaha Baru," n.d., http://ekonomi.kompasiana.com/wirausaha/2011/05/10/tanggulangin-shopsumber-wirausaha-baru/.

15 Kabupaten Sidoarjo dalam Angka BPS 2008. 


\begin{tabular}{|l|l|l|l|l|}
\hline & Jumlah & $\mathbf{1 2 . 1 2 4}$ & $\mathbf{5 0 . 1 1 6}$ & $\mathbf{1 3 7 . 0 7 7 . 6 3 7}$ \\
\hline
\end{tabular}

Berdasarkan tabel di atas tersebut dapat kita ambil kesimpulan bahwa daerah Tanggulangin mendominasi dalam jumlah hasil produksi kerajinan berbasis tas kulit. Tidak hanya mendominasi dalam jumlah produksinya saja, Tanggulangin di sini juga mendominasi dalam hal penyerapan tenaga kerja. Secara langsung dapat kita ketahui berdasarkan tabel di atas tersebut bahwa kecamatan Tanggulangin dilihat dari segi proses kegiatan perekonomiannya terutama di sektor UKM yang berbasis kerajinan kulit itu berjalan dengan cepat. Itu ditandai dengan banyaknya jumlah produk yang dihasilkan meskipun jumlah unit UKMnya lebih sedikit dari pada daerah lainnya.

Walaupun Tanggulangin dilihat dari jumlah UKMnya agak lebih sedikit dari pada daerah lainnya tetapi di sini hasil produksi akhirnya tetap menajadi milik dari Tanggulangin. Hal itu dikarenakan produk yang dihasilkan oleh daerah Tanggulangin berkualitas tinggi dan dapat bersaing dengan produk impor. Selain itu, kecekatan dan keahlian dari para pengrajin di sana juga ikut andil di dalamnya. Dari hasil jumlah produksinya yang banyak tersebut otomatis pemasukan untuk daerah Tanggulangin sendiri dan kabupaten Sidoarjo juga akan meningkat.

Dari banyaknya tenaga kerja yang terserap ke dalam UKM yang berbasis kulit di daerah Tanggulangin maka otomatis jumlah pengangguran akan semakin sedikit jumlahnya. Itu berarti setiap anggota masyarakat di sana mempunyai intensitas produktivitas yang tinggi pula. Dari tingkat produktivitas yang tinggi inilah maka setiap warga memiliki tingkat pendapatan yang semakin merata pula.

UKM yang berbasis kerjinan kulit di daerah Tanggulangin merupakan perilaku kompetitif yang dapat mendorong pasar, bukan hanya menciptakan pasar baru, tetapi menciptakan inovasi baru ke dalam pasar, sekaligus sebagai kontribusi nyata dari pengusaha UKM tersebut sebagai penentu dalam hal pertumbuhan ekonomi di daerah Tanggulangin. UKM di

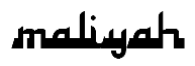


Tanggulangin ini juga telah memberikan kontribusi terhadap kinerja ekonomi daerah dengan cara memperkenalkan inovasi, menciptakan perubahan, menciptakan persaingan dan meningkatkan persaingan pasar di sana.

Dengan demikian, dalam jangka panjang eksistensi dari UKM tersebut sangatlah penting bagi pertumbuhan ekonomi dan produktivitas tinggi dari sektor UKM tersebut akan bisa meningkatkan pertumbuhan perekonomian di daerah Tanggulangin khususnya. Jadi, UKM yang berbasis kerajinan kulit di Tanggulangin tersebut telah bertindak sebagai agen perubahan dilihat dari segi perekonomiannya. Hal itu dapat terlihat bahwa UKM tersebut telah membawa ide baru untuk pasar dan merangsang pertumbuhan ekonomi melalui proses persaingan perusahaan kerajinan kulit di Tanggulangin.

Seiring dengan majunya UKM di Tanggulangin, maka itu bisa dikatakan kalau pertumbuhan perekonomian di Tanggulangin yang dihasilkan dari sektor UKM kerajinan kulit ini maka pendapatan dari daerah tersebut bisa masuk ke dalam pendapatan kota Sidoarjo. Namun, kalau itu semua tidak disertai dengan peran dari pihak pemerintah dan swasta dalam hal merangkul UKM kerajinan kulit di Tanggulangin, maka semua itu akan sia-sia belaka.

Pihak pemerintah dan swasta di sini harus bisa saling bekerjasama satu dengan lainnya. Misalkan, para pengusaha kerajinan kulit di Tanggulangin kekurangan modal usahanya. Pemerintah di sini bisa mencarikan modal usahnya melalui para investor di luar daerah Siodarjo atau di dalamnya. Pemerintah di sini juga harus bisa meyakinkan calon investor tersebut kalau prospek kerajinan kulit di Tanggulangin ini berkualitas tinggi dan mampu untuk bersaing dengan produk impor. Dengan begitu para calon investor tersebut bisa dengan yakin akan menanamkan modalnya ke UKM di Tanggulangin.

Pihak perusahaan swasta di sini juga bisa menyediakan misalkan teknologi yang modern yakni berupa mesin untuk melakukan kegiatan produksi untuk UKM tersebut. Pihak dari perusahaan swasta akan memberikan kredit dengan cicilan ringan dari penjualan mesin-mesinnya tadi, sehingga para 
pengusaha UKM tidak terlalu kesulitan untuk membayarnya. Dari mesin yang modern ini, pengusaha UKM kerajinan kulit di Tanggulangin bisa meningkatkan jumlah hasil produksinya, meningkatkan kualitas barangnya, membuat inovasi baru dari kerajinan kulit.

Dari meningkatnya jumlah mesin yang modern dan disertai dengan meningkatnya hasil produkisnya maka secara otomatis permintaan akan hasil produknya dari para konsumen maupun distributor akan naik juga. Berangkat dari kenaikan permintaan inilah maka pihak pengusaha pasti akan membutuhakan sangat banyak karyawan-karyawan baru. Dengan sendirinya perekrutan karyawan di tanggulangin akan sangat banyak terserap ke dalam UKM yang berbasis kerajinan kulit tersebut. Dengan banyaknya warga-warga di sana yang produktif karena dapat terserap ke sentra-sentra UKMnya maka setiap kepala rumah tangga di sana mendapatkan pendapatan yang merata. Dengan meratanya pendapatan antar warga inilah maka secara otomatis pengangguran di daerah tanggulangin bisa teratasi.

Saat ini pendapatan antar warga di Tanggulangin bisa merata dan penganggurannya pun bisa diatasi juga. Ini berarti menandakan bahwa kualitas taraf hidup dan perekonomiannya di Tanggulangin semakin meningkat dengan banyaknya UKM yang berbasis kulit disana. Dengan meningkatnya jumlah pendapatan dari Tanggulangin sendiri maka pajak dari pemerintah Siodarjo juga otomatis akan meningkat. Pendapatan kota Sidoarjo juga akan terangkat naik seiring naiknya pendapatan dari Tanggulangin ini.

Lingkungan usaha yang tidak kondusif, seperti adanya pungutan liar yang menggerogoti margin berimplikasi pada penurunan kemampuan melakukan akumulasi kapital, menurunkan efisiensi dan memaksanya meningkatkan harga jual sehingga menjadi sulit bersaing dalam iklim pasar yang kompetitif. Hambatan tersebut semakin melemahkan motivasi UKM untuk berkembang lebih maju melalui inovasi, perluasan pasar maupun peningkatan skala usaha. 
Peran dari pemerintah daerah sangat penting menumbuh kembangkan UKM di daerah karena pemerintah daerah yang bersentuhan langsung dengan kondisi internal dan eksternal UKM. ${ }^{16}$ siUntuk itu pemerintah perlu mengeluarkan kebijakan yang mendukung pertumbuhan dari UKM kerajinan kulit di Tanggulangin misalnya seperti:

1. Mempermudah dan menyederhanakan proses perijinan mendirikan usaha.

2. Memberikan bantuan kredit lunak dengan bunga yang rendah.

3. Memberi perlindungan terhadap produk UKM dari membanjirnya produk import.

4. Melakukan promosikan ke luar negeri agar produk-produk UKM dapat bersaing di pasar internasional.

5. Memberi pengawasan terhadap mutu produk.

6. Menghapus kebijakan yang memberatkan UKM seperti pungutan liar.

7. Memberikan pendidikan dan pelatihan.

Untuk bisa bertahan dalam meghadapi krisis global, maka ada 7 tantangan yang harus siap dihadapi UKM, yaitu:

1. Tidak adanya pembagian tugas yang jelas antara bidang administrasi dan operasi.

2. Akses industri kecil terhadap lembaga kredit formal rendah, sehingga mereka cenderung menggantungkan pembiayaan usahanya dari modal sendiri atau sumber lain, seperti keluarga, kerabat, pedagang perantara, bahkan rentenir.

3. Sebagian besar usaha kecil ditandai dengan belum dipunyainya status badan hukum.

4. Tren nilai ekspor yang sangat fluktuatif.

5. Pengadaan bahan baku. Problem pengadaan bahan baku meliputi harganya yang mahal, terbatasnya ketersediaan, dan jarak yang relatif jauh.

6. Kurangnya tenaga kerja yang terampil.

${ }^{16}$ Erna Haryanti Koestedjo, "Evaluasi Efektivitas Biaya Usaha Kecil Menengah Di Kabupaten Sidoarjo Tahun 2014,” Sosio Agribis 15, no. 1 (2015), 87. 
7. Dalam bidang pemasaran, banyak pesaing yang bergerak dalam industri yang sama. ${ }^{17}$

Agar UKM kerajinan kulit Tanggulangin khususnya siap dalam menghadapi era globalisasi maka pelaku bisnis UKM dituntut untuk kreatif, inovatif dan berani ambil resiko.

Dituntut kreatif karena kebanyakan bisnis UKM di Indonesia adalah berasal dari ide-ide kreatif yang dikembangkan. Inovatif, agar produk yang ditawarkan di pasar mempunyai daya tarik yang tinggi sehingga bisa berkompetisi dengan produk sejenis yang berasal dari luar negeri. Berani ambil resiko, karena pelaku bisnis harus mengerti resiko dan manfaat bisnis tersebut, untuk itu diperlukan manajemen resiko.

Strategi alternatif yang dapat dilakukan bagi UKM di Tanggulangin dalam menghadapi krisis global:

1. Upaya peningkatan diversifikasi poduk dan pasar tujuan ekspor.

2. Meningkatkan insentif fiskal maupun non fiskal bagi pelaku usaha khususnya sektor UKM.

3. Meminimalisasi biaya-biaya yang menyebabkan ekonomi biaya tinggi, baik terkait dengan proses birokrasi maupun kondisi-kondisi yang menciptakan ekonomi rente.

4. Mengamankan serta memperkuat pasar dalam negeri.

5. Peningkatan efisiensi dan produktivitas serta mempercepat restrukturisasi usaha.

6. Perbaikan iklim investasi dengan kebijakan yang konsisten

7. Menjaga keberlangsungan UKM dengan KUR serta program fasilitasi UKM lainnya.18

\section{Penutup}

Dari pembahasan di atas, maka terdapat beberapa kesimpulan di antaranya: dengan semakin banyak dan

\footnotetext{
${ }^{17}$ Dedy Suryadi, "Peran Dan Strategi Perkembangan Kewirausahaan Dan Tantangannya Dalam Menghadapi Perekonomian Di Masa Yang Akan Datang," in $U K M$, n.d.

18 Joe Setyawan, Strategi Efektif Berwirausaha (Jakarta: PT Gramedia Pustaka Utama, 1996), 56.
} 
berkembangnya jumlah UKM yang berbasis kerajinan kulit di Tanggulangin maka itu berdampak secara langsung pada pengurangan jumlah pengangguran dan jumlah kemiskinan di sana. Hal itu dikarenakan setiap warga di sana telah banyak terserap ke dalam sentra UKMnya sehingga setiap keluarga telah memliki pendapatan dari hasil kerjanya tersebut.

Dengan berkurangnya jumlah pengangguran dan kemiskinan di sana maka otomatis jumlah pendapatan antar keluarga juga akan semakin merata juga. Semakin banyaknya jumlah pendapatan yang diperoleh dari UKM kerajinan kulit di Tanggulangin maka pendapatan dari kota Sidoarjo juga akan terangkat naik. Di sini juga kami harapkan pihak pemerintah dan swasta ikut andil di dalam merangkul UKM. Pemerintah bisa turun tangan dan ikut campur dalam memberikan advice dan pendampingan. Selebihnya, semua harus dikerjakan menurut prinsip bisnis, bukan prinsip emosional dari pengusah UKM tersebut.

Beberapa kelebihan yang dimiliki oleh para pengusaha UKM kerajinan kulit di Tanggulangin: Pertama, memiliki daya pikir kreatif, yang meliputi: selalu berpikir jauh ke depan sehingga memiliki perencanaan tidak saja jangka pendek, namun bersifat jangka panjang. Belajar dari pengalaman orang lain, kegagalan, dan dapat terbuka menerima kritik dan saran untuk masukan pengembangan UKM. Yang kedua, Bertindak inovatif, yaitu: selalu berusaha meningkatkan efisiensi, efektivitas, dan produktivitas dalam aspek kegiatan UKM kerajinan kulit di Tanggulangin. Meningkatkan kewaspadaan dalam menghadapi persaingan bisnis di sana. Yang ketiga, Berani mengambil resiko serta mengetahui resiko dan manfaat dari suatu bisnis.

\section{Daftar Pustaka}

Afiah, Nunuy Nur. "Peran Kewirausahaan Dalam Memperkuat UKM Indonesia Menghadapi Krisis Finansial Global." Universitas Padjadjaran. 2009. https://docplayer.info/36288016-Peran-kewirausahaandalam-memperkuat-ukm-indonesia-menghadapi-krisis- 
finansial-global.html.

Bank Indonesia. Pola Pembiayaan Usaha Kecil (PPUK) Kerajinan Tas Kulit. Direktorat Kredit, BPR dan UMKM, 2004.

Koestedjo, Erna Haryanti. "Evaluasi Efektivitas Biaya Usaha

Kecil Menengah Di Kabupaten Sidoarjo Tahun 2014." Sosio Agribis 15, no. 1 (2015).

Nasional, Direktorat Jenderal Pengembangan Ekspor. "Laporan Market Brief Produk Handbag Kulit Di Korea Selatan," 2013.

Pratama, Rizky Amalia. "Implementasi Model Manajemen Pembelian Untuk Efisiensi Biaya Pembelian Bahan Baku Menggunakan Simulasi Monte Carlo Dengan Database Adempiere Studi Kasus: UKM Kerajinan Kulit Dwi Jaya Abadi, Tanggulangin, Sidoarjo." Jurnal Teknik ITS 1, no. 1 (2012).

Reswanda. "Pengaruh Orientasi Kewirausahaan Terhadap Pembelajaran Organisasi, Keunggulan Daya Saing Berkelanjutan Dan Kinerja Usaha Pada UMKM Kerajinan Kulit Berorientasi Ekspor Di Sidoarjo." Jurnal Ekonomi Akuntansi Dan Manajemen 11, no. 2 (2012).

S, Kurnia Sari D., Erma Suryani, and Radityo Prasetianto W.

"Analisa Harga Dan Pemasaran Untuk Meningkatkan Profitabilitas UKM Kerajinan Kulit Dengan Sistem Dinamik (Studi Kasus: Dwi Jaya Abadi Tanggulangin Sidoarjo)." Jurnal Teknik ITS 1, no. 1 (2012).

Setyawan, Joe. Strategi Efektif Berwirausaha. Jakarta: PT Gramedia Pustaka Utama, 1996.

Sulastri, Mimin. “No Title." Wawancara, Sidoarjo 22 April, 2012. Suryadi, Dedy. "Peran Dan Strategi Perkembangan Kewirausahaan Dan Tantangannya Dalam Menghadapi Perekonomian Di Masa Yang Akan Datang." In UKM, n.d.

"Tanggulangin Shop Sumber Wirausaha Baru," n.d. http://ekonomi.kompasiana.com/wirausaha/2011/05/10

/tanggulangin-shop-sumber-wirausaha-baru/.

Ulum, Bahrul, and Aly Anwar. Saatnya Wirausahawan Muda. Makassar: Makassarpreneur Internedia, 2010.

Wie, Thee Kian. Industrialisasi Di Indonesia. Jakarta: PT Pustaka 
Moch Mahrus Fathur Rosy, Refita Avitriani Rizalina

LP3ES, 1996.

Wijandi, Soesarsono. Pengantar Kewiraswastaan. Bandung: Sinar Baru, 1998.

\section{8 maliyah} Jurnal Hukum Bisnis Islam Volume 08, Nomor 02, Desember 2018 p-ISSN: 2088-4869/ e-ISSN: 2597-4351 